\title{
Hydrogen energy system for sustainability: Permanent solution to global energy -environmental problems
}

\author{
T. Nejat VEZIROGLU \\ Clean Energy Research Institute \\ University of Miami, Coral Gables, FL 33124, USA
}

(Received 2, October 2001 Accepted 7, December 2001)

\begin{abstract}
Fossil fuels (i.e., petroleum, natural gas and coal), which meet most of the world energy demand today, are being depleted fast. Also, their combustion products are causing the global problems, such as the greenhouse effect, ozone layer depletion, acid rains and pollution, which we are posing great danger for our environment and eventually for the life in our planet. Many engineers and scientists agree that the solution to these global problems would be to replace the existing fossil fuel system by the Hydrogen Energy System. Hydrogen is a very efficient and clean fuel. Its combustion will produce no greenhouse gases, no ozone layer depleting chemicals, little or no acid rain ingredients and pollution. Hydrogen, produced from renewable energy (e.g., solar) sources, would result in a permanent energy system, which we shall never have to change.

However, there are other energy systems proposed for the post-petroleum era, such as a synthetic fossil fuel system. In this system, synthetic gasoline and synthetic natural gas will be produced using abundant deposits of coal. In a way, this will ensure the continuation of the present fossil fuel system.

The two possible energy systems for the post-fossil fuel era (i.e., the solar hydrogen energy system and the synthetic fossil fuel system) are compared with the present fossil fuel system by taking into consideration production costs, environmental damages and utilization efficiencies. The results indicate that the solar hydrogen energy system is the best energy system to ascertain a sustainable future.
\end{abstract}

Keywords : Hydrogen, Hydrogen Energy, Sustainability

\section{ENERGY RELATED GLOBAL PROBLEMS}

Soon after the invention of the steam engine in the 1860 's, when the Industrial Revolution started to replace humans' and beasts' toil with nature's energy sources, a bright future seemed to be certain for the humankind. More and more of nature's energy, initially in the form of wood and coal, later as oil and natural gas, were being harnessed for the benefit of humans. This resulted in mass production of goods, with corresponding reduction in prices and rising living standards.

Communities asked for factories, railroads, highways, seaports and airports. These meant more jobs, more income, more goods and more services. The world's standard of living was rising. When the Industrial Revolution started, the annual gross world product per capita was in some tens of dollars; today, it is $\$ 6,600$ and rising exponentially.

Fossil fuels, which fed this amazing economic growth, were the medicine to cure deprivation. But it

\footnotetext{
*Numbers in square brackets refer to references listed at the end of the paper.

** $1 \mathrm{GJ}$ of energy is approximately equal to the energy contained in 3.4 gallons of petroleum.
} 
was an untested medicine, at that. As the planet Earth consumed more and more fossil fuels, two important predicaments started to emerge: (1) the fossil fuels would be depleted in a foreseeable future, and (2) the fossil fuels and their combustion products were causing global environmental problems.

\section{I-A. Depletion of Fossil Fuels}

The demand for energy continues to rise because of two main reasons: (a) the continuing increase in world population, and (b) the growing demand by the developing countries in order to improve their living standards. At the present time, a large portion (about 65\%) of the world energy demand is met by the fluid fossil fuels (i.e., petroleum and natural gas), because of their availability and convenient use. However, it is expected that the world fossil fuel production will soon peak, and thereafter begin to decrease. $^{1-4^{*}} \quad$ Figure 1 shows estimates of the production rates of the fossil fuels and the world demand. It can be seen that the fluid fossil fuel production worldwide will continue to rise for the next 15 years, and then will start to decrease. The coal production -because of the environmental reasons -is expected to remain nearly constant for the next decade and then start to decrease.

Meantime, as a result of the growing world population and the desires of the peoples to better their living standards, the world demand for fluid fuels is rising (Fig. 1). It is expected that the world population (which is about 6 billion at the moment and rising at $1.5 \%$ per year) growth will slow down and reach about 10 to 12 billions by the end of the next century. ${ }^{5}$ Consequently, the world demand for fluid fuels will slow down and reach around $1.6 \times 1012 \mathrm{GJ}^{* *}$ per year. There will be a growing gap, starting within the next ten years, between the demand and production of fluid fuels.

\section{I-B. Environmental Damage}

The second predicament involving the fossil fuels is the environmental damage being caused by the fossil fuels and by their combustion products. Technologies for fossil fuel extraction, transportation, processing and particularly their end use (combustion), have harmful impacts on the environment, which cause direct and indirect negative effects on the economy. Excavation of coal devastates the land, which has to be reclaimed and is out of use for several years. During the extraction, transportation and storage of oil and gas, spills and leakages occur, which cause water and air pollution. Refining processes also have an environmental impact. However, most of the fossil fuel environmental damage occurs during the end use. The end us of all fossil fuels is combustion, irrespective of the final purpose (i.e., heating, electricity production or motive power for transportation). The main constituents of fossil fuels are carbon and hydrogen, but also some other ingredients, which are originally in the fuel (e.g., sulfur), or are added during refining (e.g., lead, alcohols). Combustion of the fossil fuels produces various gases $\left(\mathrm{CO}_{\mathrm{x}}, \mathrm{SO}_{\mathrm{x}}, \mathrm{NO}_{\mathrm{x}}, \mathrm{CH}\right)$, soot and ash, droplets of tar, and other organic compounds, which are all released into the atmosphere and cause air pollution. Air pollution may be defined as the presence of some gases and particulates which are not a natural constituent of the atmosphere, or even presence of the natural constituents in an abnormal concentration. Air pollution causes damage to human health, animals, crops, structures, reduces visibility, and so on. Once in the atmosphere, triggered by sunlight or by mixing with water and other atmospheric compounds, the above stated primary pollutants may undergo chemical reactions, change their form and become secondary pollutants, like ozone, aerosols, peroxyacyl nitrates, various acids, etc. Precipitation of sulfur and nitrogen oxides, which have dissolved in clouds and in rain droplets to form sulfuric and nitric acids is called acid rain; but also acid dew, acid fog and acid snow have been recorded. Carbon dioxide in equilibrium with water produces weak carbonic acid. Acid deposition (wet or dry) causes soil and water acidification, resulting in damages to the aquatic and terrestrial ecosystems, affecting humans, animals, vegetation and structures.

The remaining products of combustion in the atmosphere, mainly carbon dioxide, together with other so called greenhouse gases (methane, nitrogen oxides and chlorofluorocarbons) $\sim$ result in thermal changes by absorbing the infrared energy the Earth radiates into the atmosphere, and by reradiating some back to Earth, causing global temperatures to increase. The effects of the temperature increase are melting of the ice caps, sea level rise and climate changes, which include heat waves, droughts, floods, stronger storms, more wildfires, etc.

Using the studies by scores of environmental scientists, the above stated damages have been calculated for each of the fossil fuels. ${ }^{6}$ Table 1 presents the results for each type of damage, in 1998 U.S. dollars. It can be seen that the environmental damage for coal is $\$ 14.51$ per GJ of coal consumed, for petroleum $\$ 12.52$ per GJ of petroleum consumed, for natural gas $\$ 8.26$ per GJ of natural gas consumed, and the weighted mean 
damage in the world is $\$ 12.05$ per GJ of fossil fuel consumption. These damage costs are not included in the prices of fossil fuels, but they are paid for by the people directly or indirectly through taxes, health expenditures, insurance premiums, and through a reduced quality of life. In other words, today fossil fuels are heavily subsidized. If the respective environmental damages were included in the fossil fuel prices, it would force earlier introduction of cleaner fuels, such as hydrogen, with many benefits to the economy and the environment.

In order to see the worldwide dimensions of the fossil fuel environmental damage, Table 2 has been prepared. It can be seen that $37 \%$ of the total damage is caused by coal, while the coal consumption is $31 \%$ of the total fossil fuel consumption. On the other hand, only $20 \%$ of the damage is caused by natural gas, which has a market share of $29 \%$. It is clear that increasing the natural gas consumption at the expense of coal and petroleum will be environmentally beneficial. This would also prepare the way for greater public acceptance of gaseous fuels, which would result in a smoother change to hydrogen, also a gaseous fuel.

It can also be seen from Table 2 that the annual worldwide environmental damage caused by fossil fuels is $1998 \$ 4,345$ billion, or equal to $11 \%$ of the gross world product. This is a very large figure. Conversion to a cleaner fuel, such as hydrogen, would enable the world to save this enormous sum and perhaps use it to improve the quality of life worldwide.

\section{REASONS FOR HYDROGEN ENERGY SYSTEM}

Because of the foregoing, energy researchers are looking at the possible alternative sources of energy to replace the fossil fuels. There are quite a number of primary energy sources available, such as thermonuclear energy, nuclear breeders, solar energy, wind energy, hydropower, geothermal energy, ocean currents, tides and waves.

At the consumer end, about one-quarter of the primary energy is used as electricity and three-quarters as fuel. The above mentioned primary energy sources must therefore by converted to these energy carriers needed by the consumer. In contrast with the fossil fuels, none of the new primary energy sources can be directly used as a fuel, e.g., for air transportation, land transportation. Consequently, they must be used to manufacture a fuel or fuels, as well as to generate electricity;

Since we need to manufacture a fuel for the post fossil fuel era, we are in a position to select the best possible fuel. There are many candidates, such as synthetic gasoline, synthetic natural gas (methane), methanol, ethanol and hydrogen. The fuel of choice must satisfy the following conditions. ${ }^{7}$

- It must be convenient fuel for transportation.

- It must be versatile or convert with ease to other energy forms at the user end.

- It must have high utilization efficiency.

- It must be safe to use.

In addition, the resulting energy system must be environmentally compatible and economical.

\section{II-A. Transportation Fuel}

Surface vehicles and airplanes must carry their fuel for a certain distance before replenishing their fuel supply. In the case of space transportation, the space vehicles must carry their fuel, as well as the oxidant, necessary for their scheduled range. Therefore, it is important that the transportation fuel be as light as possible and also take as little space as possible. We can combine these requirements in a dimensionless number, termed the motivity factor: ${ }^{8}$ where is the energy generated by the fuel, $\mathrm{M}$ the mass of the fuel, $\mathrm{V}$ the volume of the fuel, and the subscript $h$ refers to hydrogen. The higher the motivity factor, the better the fuel for transportation. Table 3 lists the pertinent properties: of some fuels, as well as the motivity factors calculated using Equation (1). It can be seen that among the liquid fuels $\mathrm{LH}_{2}$ has the best motivity factor, while methanol has the lowest motivity factor. Among the gaseous fuels, $\mathrm{GH}_{2}$ has the best motivity factor.

Consideration of the utilization efficiency advantage of hydrogen further improves hydrogen's standing as the best transportation fuel. Of course, this is one of the reasons why hydrogen is the fuel of choice for the space programs around the world, even though presently it is more expensive than fossil fuels.

\section{II-B. Versatility}

At the user end, all fuels must be converted through a process (such as combustion) to other forms of energy, e. g. , thermal energy, mechanical energy and electrical energy .If a fuel can be converted through more than one process to various forms of energy at the user end, it becomes more versatile and more convenient to utilize. Table 4 lists various fuels and processes by which they can be converted to other forms of energy at the user end. It can be seen that all the fuels, except hydrogen, can be converted through 
one process only, that of combustion. Hydrogen, however, can be converted to other forms of energy in five different ways; i.e., in addition to flame combustion, it can be converted directly to steam, converted to heat through catalytic combustion, act as a heat source and/or heat sink through chemical reactions, and converted directly to electricity through electrochernical processes. ${ }^{9}$ In other words, hydrogen is the most versatile fuel.

\section{II-C. Utilization Efficiency}

In comparing the fuels, it is important to take into account the utilization efficiencies at the user end. For utilization by the user, fuels are converted to various energy forms, such as thermal, mechanical and electrical. Studies show that in almost every instance of utilization, hydrogen can be converted to the desired energy form more efficiently than other fuels. ${ }^{6}$

Table 5 presents the utilization efficiency factors, defined as the fossil fuel utilization efficiency divided by the hydrogen utilization efficiency, for various applications. It can be seen that hydrogen is the most efficient fuel. This results in conservation of resources, in addition to conserving energy.

$$
\phi_{\mathrm{M}}=\frac{\left(\frac{\mathrm{E}}{\mathrm{M}}\right)}{\left(\frac{\mathrm{E}_{h}}{\mathrm{M}_{h}}\right)} \frac{\left(\frac{\mathrm{E}}{V}\right)^{2 / 3}}{\left(\frac{\mathrm{E}_{h}}{V_{h}}\right)^{2 / 3}}
$$

\section{II-D. Safety}

The safety aspects of fuels involve their toxicity on one hand and the fire hazard properties on the other. In addition to the toxicity of their combustion products, the fuels themselves can be toxic. The toxicity increases as the carbon-to-hydrogen ratio increases. Hydrogen and its main combustion product, water or water vapor, are not toxic. However, $\mathrm{NO}_{\mathrm{x}}$, which can be produced through the flame combustion of hydrogen (as well as through the combustion of fossil fuels) displays toxic effects.

Table 6 lists the characteristics of fuels related to fire hazards. Lower density makes a fuel safer, since it increases the buoyancy force for speedy dispersal of the fuel in case of a leak. For the same reason, higher diffusion coefficients are helpful. Higher specific heat causes a fuel to be safer, since it slows down the temperature increases for a given heat input. Wider ignition limits, lower ignition energies, and lower ignition temperatures make the fuels less safe, as they increase the limits in which a fire could commence. Higher flame temperature, higher explosion energy, and higher flame emissivity make a fuel less safe as well, since its fire would be more damaging.

Table 7 compares the safety of fuels. For each of the toxic elements and fire hazard characteristics, it ranks the fuels from 1 to 3,1 being the safest and 3 the least safe. These rankings have been summed up for each fuel in order to arrive at an overall ranking. The total rankings have been prorated to obtain the safety factors, defined as the ratio of the total ranking for hydrogen to that of a given fuel. It can be seen that hydrogen becomes the safest fuel, while gasoline is the least safe, methane being in between the two.

\section{II-E. Best Fuel}

When we look at the fuel options critically under the criteria given above, it becomes clear that hydrogen is the best transportation fuel, the most versatile fuel, the most efficient fuel and the safest fuel. In summary, hydrogen is the best fuel.

\section{HYDROGEN ENERGY SYSTEM}

As a result of the above discussion, it becomes clear that it would be expedient to manufacture hydrogen using any and all primary energy sources, in order to make up for their shortcomings. Such an energy system is then called the "Hydrogen Energy System."

Figure 2 presents a schematic diagram of the proposed hydrogen energy system. In this system, hydrogen (and oxygen) is produced in large industrial plants where the primary energy source (solar, nuclear, and even fossil) and water $\left(\mathrm{H}_{2} \mathrm{O}\right)$, the raw material, are available. For large scale storage, hydrogen can be stored underground in ex-mines, caverns and/or aquifers. Hydrogen is then transported, by means of pipelines or super tankers, to energy consumption centers. Subsequently, it is used in electricity, transportation, industrial, residential and commercial sectors as a fuel and/or an energy carrier. The by-product is water or water vapor. If flame combustion of hydrogen is used, then some $\mathrm{NO}_{\mathrm{x}}$ is also produced. Water and water vapor are recycled back, through rain, rivers, lakes and oceans, to make up for the water used in the first place to manufacture hydrogen.

The oxygen produced in the industrial plant making hydrogen could either be released into the atmosphere, or could be shipped or piped to industrial and city centers for use in fuel cells (instead of air) for electricity generation. This would have the advantage of increasing the utilization efficiency. The oxygen could be used by industry for non- energy applications, and 
also for rejuvenating the polluted rivers and lakes, or speeding up sewage treatment.

It should be noted that in the hydrogen energy system, hydrogen is not a primary source of energy. It is an intermediary or secondary form of energy or an energy carrier. Hydrogen complements the primary energy sources, and presents them to the consumer in a convenient form at the desired location and time.

Details of the hydrogen energy system, including production, storage, transportation, distribution, utilization, environmental impact and economics, can be found in the proceedings of the THEME and the World Hydrogen Energy Conferences, ${ }^{10-22}$ and in the books by Bockris, Veziroglu and Smith, ${ }^{23}$ and Veziroglu and Barbir. ${ }^{24}$

\section{COMPETING ENERGY SYSTEMS}

Essentially, there are three contending energy systems: (1) the present fossil fuel system, (2) the coal/synthetic fossil fuel system, and (3) the solar hydrogen energy system, which is a special case of the hydrogen energy system.

\section{IV-A. Fossil Fuel System}

A simplified version of today's energy system is shown in Fig. 3. Fossil fuels are used for transportation (mostly petroleum products), for heat generation in residential, commercial and industrial sectors, and for electric power generation. For transportation, mostly petroleum products are used (gasoline, diesel fuel, jet fuel, etc.). Heat generation includes space heating, domestic water heating, cooking, steam generation and direct heating and/or drying in various industrial processes. All three forms of fossil fuels are used for these purposes. In electric power generation, coal is used mainly for the base load generation, and natural gas and heating oil are used for peak load. Part of the electric power is produced by hydro and nuclear power.

In comparing with other energy systems, it can be assumed that $40 \%$ of primary energy (in fossil fuel equivalent units) will be used for thermal energy generation, $30 \%$ for electric power generation, and 30\% for transportation ( $2 / 3$ for surface transportation and $1 / 3$ for air transportation). ${ }^{23}$ Energy supplied by hydro and nuclear power plants (mostly in the form of electric power) and by other non-fossil fuel sources do not have to be taken into account, since it is assumed that it will be the same for the three systems considered. Actually, it is reasonable to expect that in the future even more electrical energy will be supplied by these sources.

When one considers the early 2000 's, it can be expected that about one half of the thermal energy will be supplied by natural gas, and the rest by petroleum fuels (fuel oil and residual oil) and coal. Coat is assumed to be the main energy source for electricity generation, gasoline for surface transportation and $j$ et fuel for air transportation. This is of course a simplified version of the fossil fuel energy system, but it is close enough to the present patterns of energy consumption, and can be used as the basis for comparisons.

\section{IV-B. Coal/Synthetic Fossil Fuel System}

Reserves of fossil fuels are finite, particularly those of oil and natural gas. Known reserves of oil and natural gas are about $8,000 \mathrm{EJ}\left(1 \mathrm{EJ}=10^{18} \mathrm{~J}\right)$, which would be enough for the next 40 years at the current consumption rate. ${ }^{24}$ If the exponential population growth and the demand growth are taken into account they would only last about 25 years. Even if the estimated additional undiscovered resources were added, that would satisfy energy needs for fluid fuels an additional 30 years or so. Coal reserves are much larger, known reserves are about 20,000 EJ, but estimated ultimately recoverable resources add up to $150,000 \mathrm{EJ}$. These large amounts of coal could eventually be used to produce synthetic liquid fuels" allowing society to continue employing the present energy system. Such a system is called the coa1/synthetic fossil fuel system, since coal is to be used to manufacture synthetic fossil fuels, as well as to be directly used for electricity generation.

In this case, it can be assumed that the present fossil fuel system will be continued by the substitution with synthetic fuels derived from coal wherever convenient and/or necessary. Patterns of energy consumption are also assumed to be unchanged (see Fig. 4). Coal will be used extensively for thermal power generation and for electric power generation, because it is much cheaper than synthetic fuels. However, some end-uses require fluid fuels. Therefore it has been assumed that synthetic natural gas (SNG) will be used for some thermal energy generation (primarily in the residential sector) and also as fuel for surface transportation, where it will share the market with synthetic gasoline. Synthetic jet fuel will be used in air transportation.

\section{IV-C. Solar Hydrogen Energy System}

If solar energy, in its direct and/or indirect forms (e.g., hydro, wind, etc.), is used to manufacture hydrogen, then the resulting system is called the "solar hydrogen energy system." In this system, both the primary and secondary energy sources are renewable 
and environmentally compatible, resulting in a clean and permanent energy system. Figure 5 presents a schematic of the solar hydrogen energy system.

In this case, it is assumed that the conversion to the hydrogen energy will take place, and one-third of hydrogen needed will be produced from hydropower (and/or wind power) and two-thirds by direct and indirect (other than hydropower) solar energy forms. The same percentage of energy demands by sectors as the above systems will be assumed.

It will further be assumed that one half of the thermal energy will be achieved by flame combustion, one quarter by steam generation with hydrogen/oxygen steam generators and the last quarter by catalytic combustion; electric power will be generated by fuel cells; one-half of the surface transportation will use gaseous hydrogen burning internal combustion engines and the other half will use fuel cells. In air transportation, both subsonic and supersonic, liquid hydrogen will be used.

\section{COMPARISON OF ENVIRONMENTAL IMPACT OF ENERGY ALTERNATIVES}

It may be best to divide this into three sections, viz., pollution, vapor generation and environmental damage

\section{V-A. Pollution}

Table 8 lists the pollutants for the three energy systems described. It can be seen that the coal/synthetic fossil system is the worst from the environmental point of view, while the solar-hydrogen energy system is the best. The solar-hydrogen system will not produce any $\mathrm{CO}_{2}, \mathrm{CO}, \mathrm{SO}_{\mathrm{x}}$, hydrocarbons or particulates, except some $\mathrm{NO}_{\mathrm{x}}$. However, the solar-hydrogen-produced $\mathrm{NO}_{\mathrm{x}}$ is much less than those produced by the other energy systems. This is due to the fact that in the solar hydrogen energy system only the flame combustion of hydrogen in air will generate $\mathrm{NO}_{\mathrm{x}}$. The other utilization processes (such as direct steam generation, use of hydrogen in fuel cells, hydriding processes, etc.) will not produce any $\mathrm{NO}_{\mathrm{x}}$.

\section{V-B. Vapor Generation}

There is a notion that the hydrogen energy system would produce more water vapor than the other energy systems, since the fuel is pure hydrogen. When on considers the problem in detail, it is found to be not so.

Only the flame combustion of fuels in air or in oxygen will produce water vapor. In the case of hydrogen those other processes mentioned earlier will not produce any water vapor. Consequently, contrary to the popular belief, the solar-hydrogen energy system will produce less water vapor than the other systems.

Global warming, which is caused by the utilization of fossil fuels, also causes an increase in water vapor generation. Assuming that the Earth' $\mathrm{s}$ mean temperature has increased by $0.5^{\circ} \mathrm{C}$ since the beginning of the Industrial revolution, ${ }^{25}$ this additional water vapor generation and that produced by the combustion of fuels have been calculated. The results are presented in Table 9. It can be seen that (1) the two fossil fuel systems generate much more additional (above natural) water vapor than the solar hydrogen energy system, (2) the additional water vapor generated by global warming is much greater than that produced by the combustion of fuels, (3) the amount of water vapor generated by fuels is minimal compared to that generated naturally, and (4) the solar- hydrogen system causes the smallest increase in vapor generation. Again, when the additional vapor generation is considered, the solar-hydrogen system becomes environmentally the most compatible system.

\section{V-C. Environmental Damage}

Table 10 presents the environmental damage per gigajoule of the energy consumed for each of the three energy systems considered and also for their fuel components in 1998 US dollars, as well as environmental compatibility factors, defined as the ratio of the environmental damage due to the hydrogen energy system to that due to a given energy system. The environmental damage for the solar-hydrogen energy system is due to the $\mathrm{NO}_{\mathrm{x}}$ produced. It can be seen that the solar-hydrogen energy system is environmentally the most compatible system.

It should be mentioned that hydrogen also has the answer to the depletion of the ozone layer, mainly caused by chlorofluorocarbons. Refrigeration and air-conditioning systems based on the hydriding property of hydrogen do not need chlorofluorocarbons but need hydrogen, and any hydrogen leak would not cause ozone layer depletion. Such refrigeration systems are also very quiet, since they do not have any moving machinery.

\section{COMPARISON OF ECONOMICS OF ENERGY ALTERNATIVES}

The economical comparison between competing energy systems should be based on the effective costs of the services these fuels provide. The effective costs include the utilization energy, the cost of fuel, and the costs associated with fuel consumption but which are not included in its price (so-called external 
costs). External costs include the costs of the physical damage done to humans, fauna, flora and the environment due to harmful emissions, oil spills and leaks, and coal strip mining, as well as governmental expenditures for pollution abatement and expenditures for military protection of oil supplies.

In economic considerations, it is also important to compare the future costs of hydrogen (which will be considerably lower than they are today because of the assumed market and technology development) with the future costs, both internal and external, of fossil fuels (which will unavoidably be higher than today's prices due to depletion, international conflicts and environmental impact).

The effective cost of a fuel can be calculated using the following relationship:

$$
C_{n}=\left(C_{i}+C_{e}\right) \frac{\eta_{f k}}{\eta_{s k}}
$$

where $\mathrm{C}_{\mathrm{i}}$ is the internal cost or the conventional cost of the fuel, $\mathrm{C}_{\mathrm{e}}$ the external cost including the application or the end use.

In order to evaluate the overall cost $\left(\mathrm{C}_{\mathrm{o}}\right)$ to society, the three scenarios considered earlier will be used. This cost can be calculated from the relationship

$$
C_{O}=\sum_{n=1}^{n} \alpha_{n} C_{n}
$$

where $\alpha_{\mathrm{n}}$ is the fraction of energy used by the energy sector $\mathrm{n}$, such as electricity generating, heat producing, surface transportation, subsonic air transportation, and supersonic air transportation. Since $\alpha_{\mathrm{n}}$

is a fraction, their sum is

$$
C_{O}=\sum_{n=1}^{n} \alpha_{n} C_{n}
$$

Substituting Eq. (2) into Eq. (3), one obtains

$$
C_{O}=\sum_{n=1}^{n} \alpha_{n}\left[\left(C_{i}+C_{e}\right) \frac{\eta_{f k}}{\eta_{s k}}\right]_{n}
$$

Using Eqs. (2)-(5), Tables 11- 13 have been prepared for the three energy scenarios, i.e., the fossil fuel system, the coal/synthetic fossil fuel system, and the solar-hydrogen energy system in 1998 US dollars. Comparing the results, it becomes clear that the solarhydrogen energy system is the most cost-effective energy system, and results in the lowest overall effective cost to society.

\section{ADVANTAGES OF HYDROGEN AND SOLAR-HYDROGEN ENERGY SYSTEM}

As a result of the investigation, presented above, it can b e seen that hydrogen as a fuel and the solar hydrogen energy system have environmental damage caused by the fuel $\eta_{f k}$ the fossil fuel utilization efficiency for unmatched advantages as compared with fossil fuels and the fossil fuel system respectively.

\section{VII-A. Hydrogen}

The advantages of hydrogen vis a vis fossil fuels can be listed as follows:

a. While hydrogen can be converted to useful energy forms (thermal, mechanical and electrical) at the user end through five different processes, fossil fuels can only be converted through one process, i.e., flame combustion. In other words, hydrogen is the most versatile fuel.

b. Hydrogen has the highest utilization efficiency when it comes to conversion to useful energy fonns (thermal, mechanical and electrical) at the user end. Overall, hydrogen is $39 \%$ more efficient than fossil fuels. In other words, hydrogen will save primary energy resources. It could also be termed as the most energy conserving fuel.

c. When fire hazards and toxicity are taken into account, hydrogen becomes the safest fuel.

d. When fire hazards and toxicity are taken into account, hydrogen becomes the safest fuel.

\section{VII-B. Solar Hydrogen Energy System}

The advantages of the solar hydrogen energy system vis a vis the present fossil fuel system and synthetic fossil fuel system can be listed as follows:

e. When the environmental impact is taken into consideration, the solar hydrogen energy system becomes the most environmentally compatible energy system. It will not produce greenhouse gases, ozone layer damaging chemicals, oil spills, climate change, and little or no acid rain ingredients 
and pollution. It will actually reverse the global warming and bring the Earth back to its normal temperatures by decreasing the $\mathrm{CO}_{2}$ in the atmosphere to its pre-Industrial Revolution level.

f. The solar hydrogen energy system has the lowest effective cost, when environmental damage and higher utilization efficiency of hydrogen are taken into account. In other words, the solar hydrogen energy system will cost society least when compared with the present fossil fuel system and the synthetic fossil fuel system.

\section{REFERENCES}

${ }^{1}$ M. A. Elliot and N. C. Turner. "Estimating the Future Rate of Production of the World's Fossil Fuels," presented at the American Chemical Society's 163rd National Meeting, Division of Fuel Chemistry Symposium on "Non-Fossil Chemical Fuels," Boston, 13 April (1972).

${ }^{2}$ D. Root and E. Attanasi, in The American Association of Petroleum Geologists Bulletin (1978).

3 J. D. Parent. " A Survey of the United States and Total World Production, Proves Reserves, and Remaining Recoverable Resources of Fossil Fuels and Uranium as of December 31, 1977," Institute of Gas Technology, Chicago, March (1979).

${ }^{4}$ J. O'M. Bockris and T. Nejat Veziroglu. Int. J Hydrogen Energy 8,323 (1983)

5 T. N. Veziroglu and 0. Basar. "Dynamics of a Universal Hydrogen Fuel System,"Hydrogen Energy. Part B, Plenum Press, pp. 1309-1326 (1974).

6 F. Barbir, T. N. Veziioglu and H. I. Plass, Ir "Environmental Damage Due to Fossil Fuels Use, "Int. J. Hydrogen Energy 10, 739 (1990).

7 T. N. Veziroglu and F. Barbir. "Hydrogen: The Wonder Fuel," Int. J. Hydrogen Energy 17,391 (1992).

8 T. N. Veziroglu and Frano Barbir. "Transportation Fuel-Hydrogen," Energy Technology and the Environment, Vol. 4, Wiley Interscience, 2712-2730 (1995).

9 T. N. Veziroglu. "Hydrogen Technology for Energy Needs of Human Settlements," Int. J. Hydrogen Energy 12(2) (1987).

${ }^{10}$ T. N. Veziroglu, ed. Hydrogen Energy, P arts A and B .proceedings Hydrogen Economy Miami Energy Conference (THEME), Plenum Press, New York, 1975.

11 T. N. Veziroglu, ed. Proc. 1st World Hydrogen Energy Conference (WHEC), 3 volumes, Clean
Energy Research Institute, University ofMiami, Coral Gables, FL, 1976.

12 T. N. V eziro glu and W. Seifritz, eds. Hydrogen Energy Pro gress ( 4 vols .), Proceedings of the 2nd WHEC, Pergamon Press, Oxford, 1979.

13 T. N. Veziroglti, K. Fueki and T. Ohta, eds. Hydrogen Energy Progress (4 vols.), Proceedings of the 3rd WHEC, Pergamon Press, Oxford, 1981

14 T. N. Veziroglu, W. D. Van Vorst, and J. H. Kelley, eds. Hydrogen Energy Progress IV(4 vols.), Proceedings of the 4 th $\sim$ C, Pergamon Press, Oxford, 1982.

15 T. N. Veziroglu and J. B. Taylor, eds. Hydrogen Energy Progress V(4 vols.), Proceedings of the 5th WHEC, Pergamon Press, Oxford, 1984.

16 T. N. V ezirogl ti, N. Getoff and P. Weinzierl, eds. Hydrogen Energy Progress VI (3 vols.), Proceedings of the 6th WHEC, Pergamon Press, Oxford, 1986.

17 T. N. Veziroglti and A. N. Protsenlco, eds Hydrogen Energy Pro gress VII (3 vols .), Proceedings of the 7th WHEC, Pergamon Press, Oxford, 1988

${ }^{18}$ T. N. Veziroglu and P. K. Takahashi, eds. Hydrogen Energy Progress VIII (3 vols.), Proceedings of the 8th WHEC, Pergamon Press, Oxford, 1990.

19 T. N.Veziroglu, C. Derive and J. Pottier, eds. Hydrogen Energy Progress IX (3 vols.), Proceedings of the 9 th $\sim C$, International Association for Hydrogen Energy, Coral Gables, FL, 1992

${ }^{20}$ D. L. Block and T. N. Veziroglti, eds. Hydrogen Energy Progress X(3 vols.), Proceedings of the 10 th WHEC, International Association for Hydro ge:n Energy, Coral Gables, FL, 1994.

${ }^{21}$ T. N. V eziro glti, C. -1. Winter, J. P. B aselt and G. Kreysa, eds. Hydrogen Energy Progress XI (3 vols. ), Proceedings of the 11 th WHEC, International Association for Hydrogen Energy, Coral Gables, FL, 1996.

22 I. C. Bolcich and T. N. Veziroglu, eds $\sim$ Hydrogen Energy Progress XII (3 vols.), Proceedings of the 12th WHEC, International Association for Hydrogen Energy, Coral Gables, FL, 1998.

23 John O'M. Boclms and T. N. Veziroglu with Debbi Smith. Solar Hvdrogen Energy: The Power to Save the Earth, Optima, London; 1991.

24 T. Nejat Veziroglu and Frano Barbir, Hydrogen Energy Technologies, UNIDO, A1400. Vienna, Austria, 1998 
T. N. V eziro glti and F. B arbir. "Hydro gen Energy System: A Permanent Solution to the Global Energy- Environmental Problems," 35th ILre AC Congress Proceedings, Istanbul, Turkey, 13-15 August 1995.

26 W. Fulkerson, R. I. Jud1cins and M. K. Sanghvi.
"Energy from Fossil Fuels," Scientific American, 263 (3), pp. 129-135, 1990.

27 N. Veziroglu, I. Gurkan and M. M. Padki,

"Remediation of Greenhouse Problem through Replacement of Fossil Fuels by Hydrogen,"Int. J Hydrogen Energy 14(4) (April 1989).

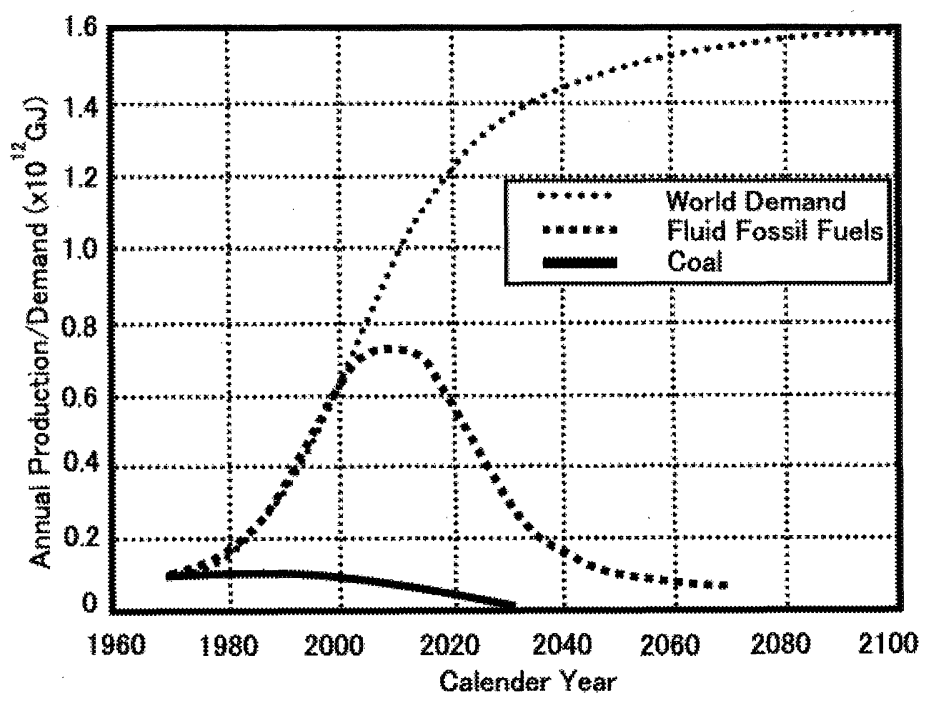

Fig. 1. Estimates of World Fossil Fuel Production. 
Table 1. Environmental Damage Caused by Each of Fossil Fuels

\begin{tabular}{|c|c|c|c|c|c|c|}
\hline \multirow[b]{3}{*}{ Type of Damage $(n)$} & \multicolumn{6}{|c|}{ Environmental Damage 1998 \$ per GJ } \\
\hline & \multicolumn{2}{|l|}{ Coal } & \multicolumn{2}{|c|}{ Petroleum } & \multicolumn{2}{|c|}{ Natural Gas } \\
\hline & $\begin{array}{l}\text { Itemized } \\
\text { Damage }\end{array}$ & $\begin{array}{l}\text { Sub- } \\
\text { Totals }\end{array}$ & $\begin{array}{l}\text { Itemized } \\
\text { Damage }\end{array}$ & $\begin{array}{l}\text { Sub- } \\
\text { Totals }\end{array}$ & $\begin{array}{l}\text { Itemized } \\
\text { Damage }\end{array}$ & $\begin{array}{l}\text { Sub- } \\
\text { Totals }\end{array}$ \\
\hline Effect on Humans & & 5.16 & & 4.19 & & 3.09 \\
\hline Premature deaths & 1.75 & & 1.42 & & 1.05 & \\
\hline Medical Expenses & 1.75 & & 1.42 & & 1.05 & \\
\hline Loss of working efficiency & 1.66 & & 1.35 & & 0.99 & \\
\hline Effect on Animals & & 0.75 & & 0.63 & & 0.45 \\
\hline Loss of domestic live stock & 0.25 & & 0.21 & & 0.15 & \\
\hline Loss of wildlife & 0.50 & & 0.42 & & 0.30 & \\
\hline Effect on Plants and Forests & & 1.99 & & 1.61 & & 1.20 \\
\hline Crop yield reduction -ozone & 0.25 & & 0.21 & & 0.15 & \\
\hline Crop yield reduction - acid rains & 0.13 & & 0.10 & & 0.07 & \\
\hline Effect on wild flora (plants) & 0.77 & & 0.62 & & 0.46 & \\
\hline Forest decline (economic value) & 0.27 & & 0.22 & & 0.16 & \\
\hline $\begin{array}{l}\text { Forest decline (effect on biological } \\
\text { diversity) }\end{array}$ & 0.53 & & 0.43 & & 0.33 & \\
\hline Loss of recreational value & 0.04 & & 0.03 & & 0.03 & \\
\hline Effect on Aquatic Ecosystems & & 0.26 & & 1.55 & & 0.16 \\
\hline Oil spills & - & & 0.44 & & - & \\
\hline Underwater tanks leakages & - & & 0.90 & & - & \\
\hline Liming lakes & 0.04 & & 0.03 & & 0.03 & \\
\hline Loss of fish population & 0.04 & & 0.03 & & 0.03 & \\
\hline Effect on biological diversity & 0.18 & & 0.15 & & 0.10 & \\
\hline Effect on Man-Made Structures & & 1.66 & & 1.34 & & 0.98 \\
\hline $\begin{array}{l}\text { Historical buildings and monuments } \\
\text { degradation }\end{array}$ & 0.18 & & 0.15 & & 0.10 & \\
\hline Buildings and houses' detriment & 0.37 & & 0.30 & & 0.22 & \\
\hline Steel constructions corrosion & 0.99 & & 0.80 & & 0.59 & \\
\hline Soiling of clothes, cars, etc. & 0.12 & & 0.09 & & 0.07 & \\
\hline Other Air Pollution Costs & & 1.45 & & 1.16 & & 0.88 \\
\hline Visibility reduction & 0.30 & & 0.23 & & 0.18 & \\
\hline Air pollution abatement costs & 1.15 & & 0.93 & & 0.70 & \\
\hline Effect of Strip Mining & & 0.73 & & - & & - \\
\hline Effect of Climactic Changes & & 2.04 & & 1.66 & & 1.22 \\
\hline Heat waves - effects on humans & 0.27 & & 0.22 & & 0.16 & \\
\hline Droughts - & & & & & & \\
\hline Agricultural losses & 0.16 & & 0.13 & & 0.10 & \\
\hline Livestock losses & 0.13 & & 0.10 & & 0.07 & \\
\hline Forests losses & 0.16 & & 0.13 & & 0.10 & \\
\hline Wild flora and fauna losses & 0.93 & & 0.75 & & 0.56 & \\
\hline $\begin{array}{l}\text { Water shortage and power production } \\
\text { problems }\end{array}$ & 0.25 & & 0.21 & & 0.15 & \\
\hline Floods & 0.07 & & 0.06 & & 0.04 & \\
\hline Storms, hurricanes, tornadoes & 0.07 & & 0.06 & & 0.04 & \\
\hline Effect of Sea Level Rise & & 0.47 & & 0.38 & & 0.28 \\
\hline TOTALS & & 14.5 & & 12.52 & & 8.26 \\
\hline
\end{tabular}


Table 2. Worldwide Fossil Fuel Consumption and Environmental Damage for 1998

\begin{tabular}{|l|c|}
\hline Fossil Fuel Consumption & $\left(10^{18} \mathrm{~J}\right.$ per year) \\
World coal consumption & 112 \\
World petroleum consumption & 148 \\
World natural gas consumption & 105 \\
World fossil fuel consumption & 365 \\
\hline Environmental Damage Estimate & $(1998$ billion $\$)$ \\
Damage due to coal & 1,625 \\
Damage due to petroleum & 1,853 \\
Damage due to natural gas & 867 \\
Total Damage & 4,345 \\
\hline Demographic and Economic Data & \\
World population (in billions) & 5.96 \\
Damage per capita & 730 \\
World GWP (billion \$) & $\$ 39,340$ \\
GWP per capita & $\$ 6,600$ \\
\cline { 2 - 2 } Damage/GWP & 0.11 \\
\cline { 2 - 2 } & \\
\cline { 2 - 2 } & \\
\cline { 2 - 2 } & \\
\cline { 2 - 2 } & \\
\cline { 2 - 2 } & \\
\hline
\end{tabular}

Table 3. Energy Densities (HHV) and Motivity Factors for Liquid and Gaseous Fuels

\begin{tabular}{|c|c|c|c|c|}
\hline Fuel & $\begin{array}{l}\text { Chemical } \\
\text { Formula }\end{array}$ & $\begin{array}{c}\text { Energy per unit } \\
\qquad \begin{array}{c}\text { mass }\left(\frac{E}{M}\right) \\
\mathrm{J} / \mathrm{kg}\end{array}\end{array}$ & $\begin{array}{c}\text { Energy per unit } \\
\text { volume }\left(\frac{\mathrm{E}}{V}\right) \\
\mathrm{J} / \mathrm{m}^{3}\end{array}$ & $\begin{array}{c}\text { Motivity } \\
\text { Factor } \\
\phi_{\mathrm{M}}\end{array}$ \\
\hline \multicolumn{5}{|l|}{ Liquid Fuels } \\
\hline Fuel oil & $\mathrm{C} \leq_{20} \mathrm{H} \leq_{42}$ & 45.5 & 38.65 & 0.78 \\
\hline Gasoline & $\mathrm{C}_{5}-{ }_{10} \mathrm{H}_{12}-{ }_{22}$ & 47.4 & 34.85 & 0.76 \\
\hline Jet fuel & $\mathrm{C}_{10-15} \mathrm{H}_{22-32}$ & 46.5 & 35.30 & 0.75 \\
\hline LPG & $\mathrm{C}_{3-4} \mathrm{H}_{8-10}$ & 48.8 & 24.40 & 0.62 \\
\hline LNG & $\sim \mathrm{CH}_{4}$ & 50.0 & 23.00 & 0.61 \\
\hline Methanol & $\mathrm{CH}_{3} \mathrm{OH}$ & 22.3 & 18.10 & 0.23 \\
\hline Ethanol & $\mathrm{C}_{2} \mathrm{H}_{5} \mathrm{OH}$ & 29.9 & 23.60 & 0.37 \\
\hline $\mathrm{LH}_{2}$ & $\mathrm{H}_{2}$ & 141.9 & 10.10 & 1.00 \\
\hline \multicolumn{5}{|l|}{ Gaseous Fuels } \\
\hline Natural gas & $\mathrm{CH}_{4}$ & 50.0 & 0.040 & 0.75 \\
\hline $\mathrm{GH}_{2}$ & $\mathrm{H}_{2}$ & 141.9 & 0.013 & 1.00 \\
\hline
\end{tabular}


Table 4. Versatility (Convertibility) of Fuels

\begin{tabular}{|l|c|c|}
\hline \multicolumn{1}{|c|}{ Conversion Process } & Hydrogen & Fossil Fuels \\
\hline Flame Combustion & Yes & Yes \\
Direct Steam Production & Yes & No \\
Catalytic Combustion & Yes & No \\
Chemical Conversion (Hydriding) & Yes & No \\
Electrochemical Conversion (Fuel & Yes & No \\
Cells) & & \\
\hline
\end{tabular}

Table 5. Utilization Efficiency Comparisons of Fossil Fuels and Hydrogen

\begin{tabular}{|l|c|}
\hline \multicolumn{1}{|c|}{ Application } & Utilization Efficiency Factor $\phi_{u}=\eta_{F} / \eta_{\mathrm{H}}$ \\
\hline Thermal Energy & 1.00 \\
Flame Combustion & 0.80 \\
Catalytic Combustion & 0.80 \\
Steam Generation & 0.54 \\
\hline Electric Power, Fuel Cells & \\
\hline Surface Transportation & 0.82 \\
Internal Combustion Engines & 0.40 \\
Fuel Cells/Electric Motor & 0.84 \\
\hline Subsonic Jet Transportation & 0.72 \\
\hline Supersonic Jet Transportation & 0.72 \\
\hline Weighted Average & 1.00 \\
Hydrogen Utilization Efficiency Factor & 0.72 \\
\hline Fossil Fuel Utilization Efficiency Factor & \\
\hline
\end{tabular}

Table 6. Characteristics Related to Fire Hazard of Fuels

\begin{tabular}{|c|c|c|c|}
\hline Property & Gasoline & Methane & Hydrogen \\
\hline Density $\left(\mathrm{kg} / \mathrm{m}^{3}\right)$ & 4.40 & 0.65 & 0.084 \\
\hline Diffusion Coefficient in Air $\left(\mathrm{cm}^{2} / \mathrm{sec}\right)$ & 0.05 & 0.16 & 0.610 \\
\hline Specific Heat at Constant Pressure ${ }^{a}(\mathrm{~J} / \mathrm{g} \mathrm{K})$ & 1.20 & 2.22 & 14.89 \\
\hline Ignition Limits in Air (vol \%) & $1.0-7.6$ & 5.3- 15.0 & $4.0-75.0$ \\
\hline Ignition Energy in Air (mJ) & 0.24 & 0.29 & 0.02 \\
\hline Ignition Temperature $\left({ }^{\circ} \mathrm{C}\right)$ & $228-471$ & 540 & 585 \\
\hline Flame Temperature in $\operatorname{Air}\left({ }^{\circ} \mathrm{C}\right)$ & 2197 & 1875 & 2045 \\
\hline Explosion Energyb (g TNT/kJ) & 0.25 & 0.19 & 0.17 \\
\hline Flame Emissivity (\%) & $34-43$ & $25-33$ & $17-25$ \\
\hline
\end{tabular}

${ }^{\text {a }}$ At normal temperature and pressure.

b Theoretical maximum; actual $10 \%$ of theoretical. 
Table 7. Safety Ranking of Fuels

\begin{tabular}{|c|c|c|c|}
\hline \multirow[t]{2}{*}{ Characteristic } & \multicolumn{3}{|c|}{ Fuel Ranking $^{\text {a }}$} \\
\hline & Gasoline & Methane & Hydrogen \\
\hline Toxicity of Fuel & 3 & 2 & 1 \\
\hline Toxicity of Combustion (GO, Sox, NOx, HC, PM) & 3 & 2 & 1 \\
\hline Density & 3 & 2 & 1 \\
\hline Diffusion Coefficient & 3 & 2 & 1 \\
\hline Specific Heat & 3 & 2 & 1 \\
\hline Ignition Limit & 1 & 2 & 3 \\
\hline Ignition Energy & 2 & 1 & 3 \\
\hline Ignition Temperature & 3 & 2 & 1 \\
\hline Flame Temperature & 3 & 1 & 2 \\
\hline Explosion Energy & 3 & 2 & 1 \\
\hline Flame Emissivity & 3 & 2 & 1 \\
\hline TOTALS & 30 & 20 & 16 \\
\hline Safety Factor $\phi_{\mathrm{s}}$ & 0.53 & 0.80 & 1.00 \\
\hline
\end{tabular}

a 1 , safest; 2 , less safe; 3 , least safe.

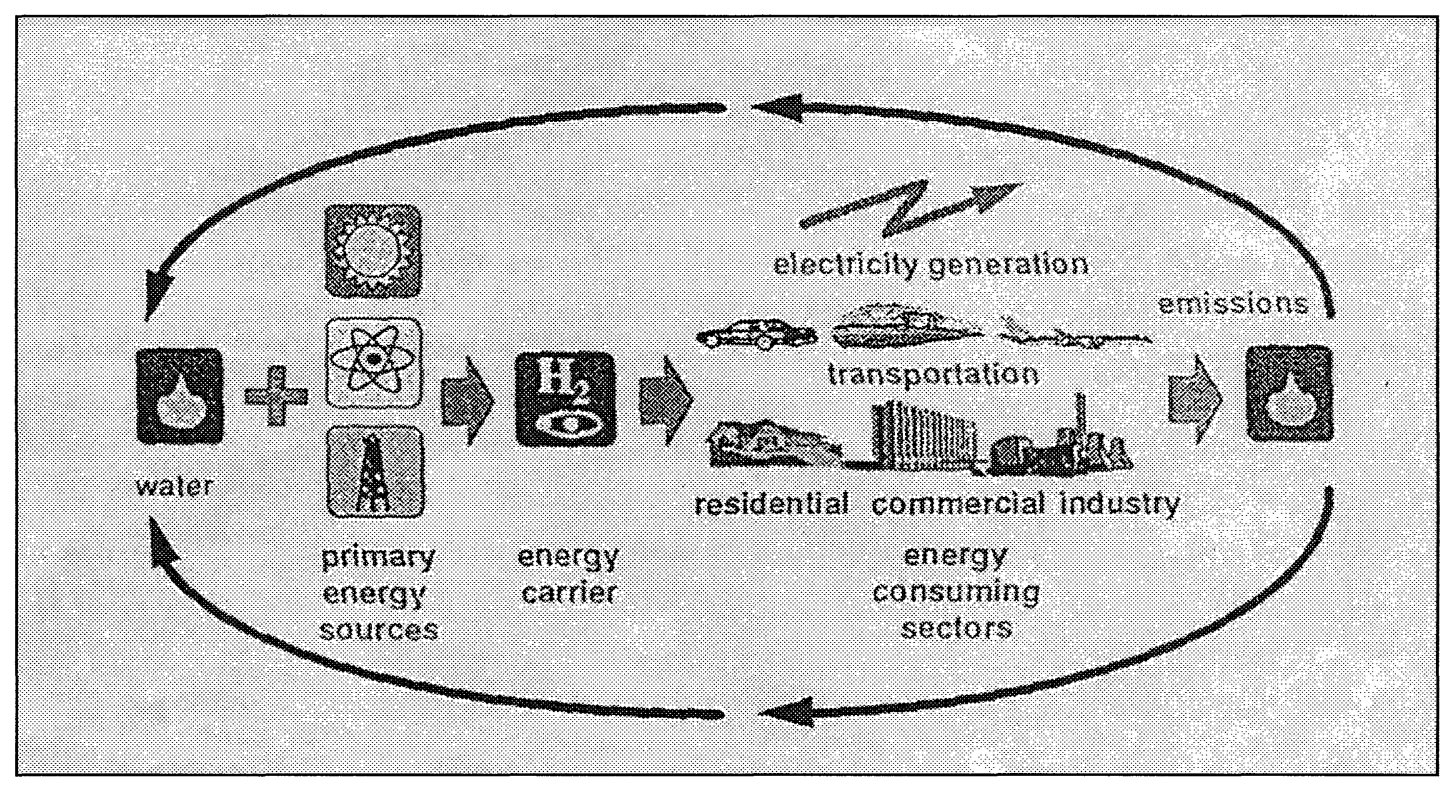

Fig. 2. A Schematic Diagram of Hydrogen Energy System.

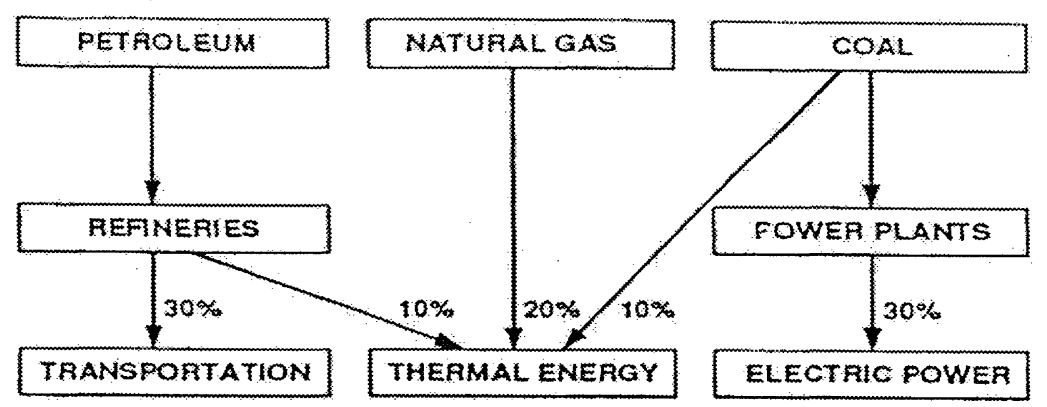

Fig. 3. Fossil Fuel System. 


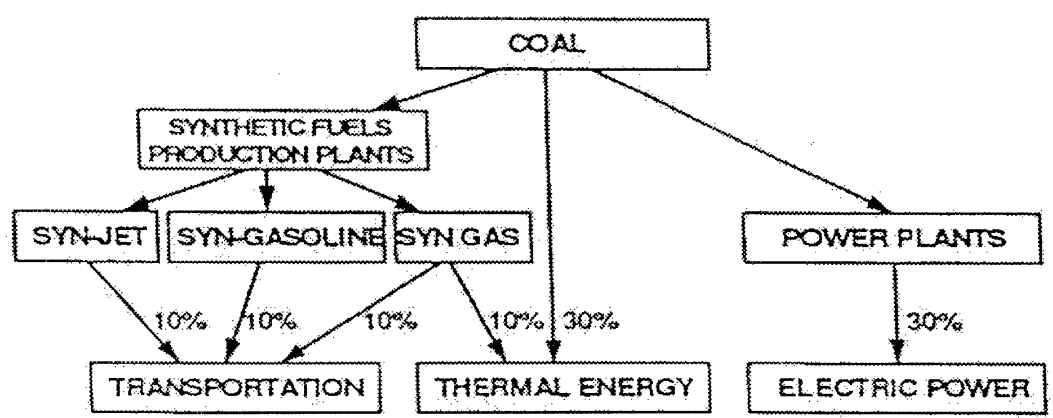

Fig. 4. Coal / Synthetic Fossil Fuel System.

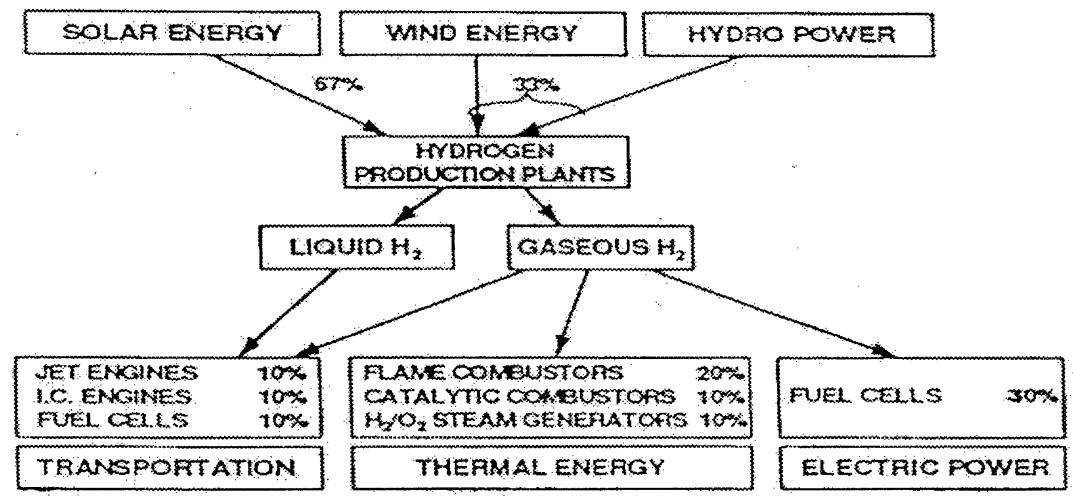

Fig. 5. Solar-Hydrogen Energy System.

Table 8. Pollutants Produced by Three Energy Systems

\begin{tabular}{|c|c|c|c|}
\hline Pollutant & $\begin{array}{c}\text { Fossil Fuel } \\
\text { System } \\
\text { (kg/GJ) }\end{array}$ & $\begin{array}{c}\text { Coal/Synthetic } \\
\text { Fossil System } \\
\text { (kg/GJ) }\end{array}$ & $\begin{array}{c}\text { Solar-Hydrogen } \\
\text { System } \\
\text { (kg/GJ) }\end{array}$ \\
\hline $\mathrm{CO}_{2}$ & 72.40 & 100.00 & 0 \\
$\mathrm{CO}$ & 0.80 & 0.65 & 0 \\
$\mathrm{SO}_{2}$ & 0.38 & 0.50 & 0 \\
$\mathrm{NO}$ & 0.34 & 0.32 & 0.10 \\
$\mathrm{HG}$ & 0.20 & 0.12 & 0 \\
PM $^{*}$ & 0.09 & 0.14 & 0 \\
\hline
\end{tabular}


Table 9. Comparison of Vapor Generation by Three Energy Systems (for 1998 Energy Consumption)

\begin{tabular}{|c|c|c|c|c|}
\hline Item & Unit & $\begin{array}{c}\text { Fossil Fuel } \\
\text { System }\end{array}$ & $\begin{array}{l}\text { Coal/Synthetic } \\
\text { Fossil System }\end{array}$ & $\begin{array}{l}\text { Solar- } \\
\text { Hydrogen } \\
\text { System }\end{array}$ \\
\hline \multirow{2}{*}{$\begin{array}{c}\text { Annual Vapor Generation by Energy } \\
\text { System }\end{array}$} & $1012 \mathrm{~kg}$ & 8.9 & 9.300 & 6.0 \\
\hline & & & & \\
\hline \multirow{2}{*}{$\begin{array}{l}\text { Annual Vapor Generation due to } \\
\text { Global Warming }\end{array}$} & $1012 \mathrm{~kg}$ & 3,900 & $3,900.000$ & 0 \\
\hline & & & & \\
\hline \multirow{2}{*}{$\begin{array}{l}\text { Total Vapor Generation due to } \\
\text { Energy System and Global Warming }\end{array}$} & $1012 \mathrm{~kg}$ & 3,909 & $3,909.000$ & 6.0 \\
\hline & & & & \\
\hline \multirow{2}{*}{$\begin{array}{c}\text { Total Vapor Generation as Fraction of } \\
\text { that Produced Naturally }\end{array}$} & $\%$ & 0.782 & 0.782 & 0.001 \\
\hline & & & & \\
\hline
\end{tabular}

Note: Annual vapor generation due to solar heating is $5 \times 10^{17} \mathrm{~kg}$.

\section{Table 10. Environmental Damage and Environmental Compatibility Factors}

\begin{tabular}{|l|c|c|}
\hline \multicolumn{1}{|c|}{ Energy System and Fuel } & $\begin{array}{c}\text { Environmental Damage } \\
(1998 \$ / G J)\end{array}$ & $\begin{array}{c}\text { Environmental } \\
\text { Compatibility Factor, } \\
\phi_{\mathrm{E}}\end{array}$ \\
\hline Fossil Fuel System & 12.47 & 0.055 \\
Coal & 14.51 & \\
Oil & 12.52 & \\
Natural Gas & 8.26 & 0.044 \\
\hline Coal/Synthetic Fossil System & 15.46 & \\
Syn-Gas & 20.34 & 1.000 \\
SNG & 13.49 & \\
\hline Solar-Hydrogen Energy System & 0.68 & \\
Hydrogen & 0.68 & \\
\hline
\end{tabular}

Table 11. Effective Cost of Fossil Fuel System

\begin{tabular}{|l|c|c|c|}
\hline \multicolumn{1}{|c|}{ Application } & Fuel & $\begin{array}{c}\text { Energy Consumption } \\
\text { Fraction }\end{array}$ & $\begin{array}{c}\text { Effective Cost (1998 } \\
\text { U.S. \$/GJ) }\end{array}$ \\
\hline Thermal Energy & Natural Gas & 0.20 & 17.46 \\
& Petroleum Fuels & 0.10 & $27.56^{\star}$ \\
& Coal & 0.10 & 17.75 \\
\hline Electric Power & Coal & 0.30 & 17.25 \\
\hline Surface Transportation & Gasoline & 0.20 & 31.61 \\
\hline Air Transportation & Jet Fuel & 0.10 & 25.98 \\
\hline TOTAL OF FRACTIONS & & 1.00 & \\
\hline OVERALL EFFECTIVE & & & 22.11 \\
COST & & & \\
\hline
\end{tabular}

* Average for residential and industrial sector. 
Table 12. Effective Cost of Coal/Synthetic Fuel System

\begin{tabular}{|c|c|c|c|}
\hline Application & Fuel & $\begin{array}{c}\text { Energy } \\
\text { Consumption } \\
\text { Factor }\end{array}$ & $\begin{array}{l}\text { Effective Cost } \\
\text { (1998 U.S.\$/GJ) }\end{array}$ \\
\hline \multirow{2}{*}{ Thermal Energy } & Coal & 0.30 & 17.75 \\
\hline & SNG & 0.10 & 36.64 \\
\hline Electric Power & Coal & 0.30 & 17.25 \\
\hline \multirow{2}{*}{ Surface Transportation } & SNG & 0.10 & 36.64 \\
\hline & Syn-gasoline & 0.10 & 51.65 \\
\hline Air Transportation & Syn-jet & 0.10 & 45.45 \\
\hline TOTAL OF FRACTIONS & & 1.00 & \\
\hline OVERALL EFFECTIVE COST & & & 27.55 \\
\hline
\end{tabular}

Table13. Effective Cost of Solar-Hydrogen Energy System

\begin{tabular}{|c|c|c|c|}
\hline Application & Fuela & $\begin{array}{c}\text { Energy } \\
\text { Consumption } \\
\text { Factor }\end{array}$ & $\begin{array}{l}\text { Effective Cost } \\
\text { (1998 US\$/GJ) }\end{array}$ \\
\hline \multicolumn{4}{|l|}{ Thermal Energy } \\
\hline Flame Combustion & $\mathrm{GH}_{2}$ & 0.20 & 26.04 \\
\hline Steam Generation & $\mathrm{GH}_{2}$ & 0.10 & 20.83 \\
\hline Catalytic Combustion & $\mathrm{GH}_{2}$ & 0.10 & 20.83 \\
\hline \multicolumn{4}{|l|}{ Electric Power } \\
\hline $\begin{array}{r}\text { Fuel Cells } \\
\end{array}$ & $\mathrm{GH}_{2}$ & 0.30 & 14.06 \\
\hline Surface Transportation & $\mathrm{GH}_{2}$ & & \\
\hline IC Engines & $\mathrm{GH}_{2}$ & 0.10 & 21.36 \\
\hline Fuel Cells & $\mathrm{GH}_{2}$ & 0.10 & 10.41 \\
\hline \multicolumn{4}{|l|}{ Air Transportation } \\
\hline Subsonic & $\mathrm{LH}_{2}$ & 0.05 & 26.26 \\
\hline Supersonic & $\mathrm{LH}_{2}$ & 0.05 & 22.51 \\
\hline TOTAL OF FRACTIONS & & 1.00 & \\
\hline OVERALL EFFECTIVE COST & & & 19.23 \\
\hline
\end{tabular}

${ }^{a}$ It has been assumed that $1 / 3$ of hydrogen will be produced from hydropower and/or wind power, and $2 / 3$ from solar. 